\title{
AOR
}

Selected Papers of \#AolR2018:

The $19^{\text {th }}$ Annual Conference of the

Association of Internet Researchers

Montréal, Canada / 10-13 October 2018

\section{VOICES EMPOWERED: IRANIAN WOMEN AND WEBLOGS}

Tannaz Zargarian

York University

\section{Voices Empowered: Iranian Women and Weblogs}

In 1998, access to the internet-the digital realm—created a unique space encompassing both public and private structures of Iranian society. This realm offers a new language and new forms of communication, identity, community, political debate, and public participation (Rheingold, 2000). Beginning in 2001, the accessibility and affordability of both digital technologies and the internet, followed by the availability of the Farsi language in the Unicode system, increased the use of cyberspace among Iranians (Amir-Ebrahimi, 2008). Along with the availability of the Farsi language, platforms such as "weblogistan" led blogging to become one of the most popular online activities among Iranians. While institutionalized gender roles and customary law (urf) are the most important elements in restricting women's emancipation in the public and private realms, the digital space altered the meaning of constraint and shifted the boundaries of the public and private realms by allowing Iranian women to seek an independent identity and self-determination (Graham, et al., 2010). Young Iranian women began to embrace weblogs as a unique public space suitable for new forms of self-expression, self-disclosure, and communication (Amir-Ebrahimi, 2008). Women gained access to a technology that did not contain the censorship of traditional mass media, hence the internet unveiled Iranian women's voices by circumventing customary practices and institutionalized gender roles (Skalli 2006, Amir- Ebrahimi, 2008, p. 98).

The broad theme of this paper is analysis of the discourse of feminism and gender equality among Iranian women and the potential for and limitations of equal rights awareness and practice. Theoretically, I draw upon Minoo Derayeh's theory "I act therefore I am" (2010). Derayeh's theory argues that Iranian women "challenged gender-based discrimination and focused on women's procedures for developing an independent identity," which then "created opportunities for women to raise their voices and take action as a means to self-liberation" (Derayeh, 2010, p. 151). Taking a critical textual feminist approach and focusing on actions, I explore how Iranian female

Suggested Citation (APA): Zargarian Voices Empowered: Iranian Women and Weblogs . (2018, October 10-13) Paper presented at AoIR 2018: The $19^{\text {th }}$ Annual Conference of the Association of Internet Researchers. Montréal, Canada: AolR. Retrieved from http://spir.aoir.org. 
university students adopted the weblog as a new tool to quest for their emancipation and brings forth the voices of female university students from different disciplines. Weblogs serve as an educational tool that creates a forum for dialogue and communication that breaks the restrictive gender-oriented rules imposed upon Iranian women by urf (customary law) and the patriarchal elements in higher education and the public realm (Van de Donk, 2004, p. 5).

\section{Quest for Equality in Weblogs}

This study divided the weblogs written by 35 Iranian female university students into two categories: experiences in higher education including academic achievements, and personal daily experiences as female students. With respect to their academic experience, the women explicitly elaborated on their personal academic performance, achievements, participation, and learning experiences. They shared their goals and plans for pursuing higher education by discussing available educational options, steps they had taken, and obstacles that they encountered. The webloggers also discussed their individual academic participation in related activities such as conferences, workshops, volunteer work, and paid temporary student work. Moreover, they turned weblogs into an informative communication tool to share information regarding scholarly articles, their field of study, available degrees at the undergraduate and graduate levels, and the procedure for continuing education at a higher level. Iranian women adopted online information sharing as a tool to subtly challenge gender inequality within higher education.

The absence of the discourse of gender inequality in a patriarchal educational system that has been cultivating institutionalized gender policies to restrict women's access to higher education might perplex one's understanding of these women's awareness of gender inequality in relation to education. However, applying the theory of "I act therefore I am" revealed that these women are aware of gender inequality in higher education, but they challenge it by ignoring and resisting the existence of institutionalized gender inequality and discrimination. Adopting non-traditional independent gender identity, they expound their achievements, level of knowledge, future academic goals, and autonomous decision making in their pursuit of higher education. The students' voiced their narration of successes as well as their autonomous academic actions in the public realm. Their narration conveys their empowerment and challenges the patriarchy by changing the direction of "I act" in sharing their achievements. Furthermore, they challenge customary law and institutionalized gender roles by voicing their experiences and knowledge as a form of empowerment through weblogging. They problematized the issue by declaring their autonomous and independent identity as a student instead of holding their expected relational identity as daughter, wife, sister, or mother. Therefore, the unique selfexpression of online activities combined with their educational accomplishments in the real world made explicit statements regarding gender equality unnecessary.

While women's participation in higher education facilitated their access to social equality in some areas, with respect to personal daily experiences, the weblogs identify women's struggle with discrimination and restrictive gender roles in their everyday interaction. In other words, gender inequality continues to obstruct women's emancipation during their 
university years. The bloggers' personal non-academic narration contained memories of sexual harassment such as offers from their professors in exchange for passing grades, blackmail by male students, and discriminatory attire laws such as mandated hijab in some universities. Some weblogs shared details of being denied entry onto university campuses due to clothing or makeup. Moreover, bloggers discussed limitations and restrictions on their interaction with the opposite sex and the negative perception sometimes associated with being a female university student. Raising their voices through self-disclosure and sharing allowed these women to gain an opportunity for public awareness and personal support through communication and dialogue while breaking the silence about forbidden matters in the digital realm.

\section{Feminism and Cyber-Feminism Among Iranian Women}

Iranian women's participation in cyber-feminism, for the purpose of emancipation, constructed a neutral environment with less governmental and societal surveillance and with the potential for empowerment through personal narration (Batmanghelichi \& Mouri, 2017). However, traditional societal values still impose some limitations on the digital realm. The paradox between traditional values of silence, invisibility, piety, and subordination, mixed with the modern expectation of public activity, assertiveness, and education limit and empower women simultaneously (Haghighat, 2014).

\section{Conclusion}

The emergence of the digital realm, as a new and unique public space with dialogical elements, has allowed women to unveil and share their personal narration, and it has provided women with a crucial venue for an autonomous and anonymous quest for their rights. In the context of "I act therefore I am," analysis of the weblogs confirms that the majority of these Iranian female university students are challenging gender-based discrimination by voicing their academic achievements, knowledge, and empowerment along with their daily experience of university life. As evidenced in the blogs, the feeling of empowerment was significantly lower in the women's daily personal experiences than in their academic experiences, but the bloggers still benefited from the weblogs by expressing their daily frustrations with gender inequality. The quest for rights continues for these women despite ongoing challenges in the real world and in the digital realm. The digital realm has become a tool for all women and many women's voices remain veiled as not all Iranian women support an autonomous voice in the digital realm. 


\section{References}

Amir-Ebrahimi, M. (2006). Conquering enclosed public spaces. cities, 23(6), 455-461.

Amir-Ebrahimi, M. (2008). Blogging from Qom, behind walls and veils. Comparative Studies of South Asia, Africa and Middle East, 28(2), 235-249.

Batmanghelichi, S. \&. (2017). Cyberfeminism, Iranian style: online feminism in post2009 Iran. Feminist Media Histories, 3(1), 50-80.

Derayeh, M. (2006). Gender equity in Iranian history. New York: Edwin Mellen Press.

Derayeh, M. (2011). The myths of creation and hijab: Iranian women, liberated or oppressed? Alam-E-Niswan, 18(2), 1-21.

Derayeh, M. (2014). De-hyphenate and de-theorize my voice: I act, therefore, I am. International Journal of Liberal Arts and Social Science, 2(3), 99-108.

Gajjala, R. (2005). Cyber selves: feminist ethnographies of South Asian women. Altamira Press.

Graham, M., \& Khosravi, S. (2010). Reordering public and private in Iranian cyberspace: Identity, politics, and mobilization. Identities, 9(2), 219-246.

Haghighat, E. (2014). Iran's changing gender dynamics in light of demographic, political, and technological transformations. Middle East Critique, 23(3), 313-332.

Irandataportal. (2016). Retrieved from Iranian Center for Statistics: http://irandataportal.syr.edu/socio-economic-data/statistical-yearbook

Jones, S. (1997). Virtual culture: identity and communication in cybersociety. London: Sage.

Mehran, G. (1999). Lifelong learning: new Opportunities for women in a Muslim country (Iran). Comparative Education, 35, 203.

Moghaddam, V. (2000). Transnational feminist networks collective action in an era of globalization. International Sociology, 15(1).

Mohanty, C. T. (2003). Feminism without border: decolonizing theory, practicing solidarity. Duke University Press.

Najmabadi, A. (1993). Veiled discourse- unveiled bodies. Feminist Studies, 10, 487518. 
Nouraei-Simon, F. (2005). Wings of freedom: Iranian women, identity, and cyberspace. In I. F. Nouraei-Simon, On shifting ground (pp. 61-79). New York: Feminist Press.

Rheingold, H. (2000). The virtual community: homesteading on the electronic frontier. Cambridge: The MIT Press.

Shavarini, M. K. (2005). The feminization of Iranian higher education. International Review of Education , 51(4), 329-347.

Shirazi, F. (2012). Information and communication technology and women empowerment in Iran. Telematics and Informatics, 29, 45-55.

Skalli, L. H. (2006). Communicating gender in the public sphere: women and information technologies in the MENA. . Journal of Middle East Women's Studies, 2(2).

Sreberny, A., \& Khiabany, G. (2010). Blogistan: The Internet and politics in Iran. London: I.B. Tauris.

Taheri, J. (2011). Areas of Iranian women's voice and influence. In R. \&. Bahramitash, Gender in contemporary Iran: pushing the boundaries. Routledge.

Van de Donk, L. N. (2004). Cyberprotest. London and New York: Routledge. 